\title{
Guide RNA
}

National Cancer Institute

\section{Source}

National Cancer Institute. Guide RNA. NCI Thesaurus. Code C95952.

A small RNA involved in post-transcriptional mitochondrial RNA modification (RNA editing) in kinetoplastid protists. 